\title{
Takaisin kasvatusopin perusteisiin
}

\author{
Juha Hämäläinen
}

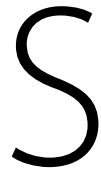

uomessa on tänä syksynä uutisoitu näyttävästi lasten ja nuorten sekä nuorten aikuisten mielenterveysongelmien merkittävästä kasvusta. Kyse on pitkään jatkuneesta trendistä, jota koronapandemiasta aiheutuneet poikkeukselliset olosuhteet ovat ilmeisesti entisestään voimistaneet.

Ihmisen mielenterveyttä, sen edellytyksiä ja siihen liittyviä ongelmia voidaan tarkastella monesta näkökulmasta ja kovin erilaisissa viitekehyksissä. Varsinkin varttuvan sukupolven mielenterveydestä puhuttaessa on luontevaa käyttää pedagogisia silmälaseja, joiden läpi mielenterveyden rakentuminen näyttäytyy olennaisesti kasvatuskysymyksenä.

Tieteen kielellä kyse on siitä, miten mielenterveys ja sen ehdot käsitteellistetään ja selitetään. Pedagoginen näkökulma eroaa psykologisesta, sosiologisesta, psykiatrisesta ja vaikkapa taloustieteellisestä tavasta puhua mielenterveydestä. Sama koskee muitakin ihmiselämän aiheita. Kullakin tieteenalalla on myös erilaisia sisäisiä puhetapoja, jotka liittyvät erilaisiin teorioihin ja teoriaperinteisiin.

Myös pedagogiikassa on keskenään kilpailevia koulukuntia, jotka perustavat kasvatusoppinsa erilaisiin filosofisiin ja katsomuksellisiin lähtökohtiin. Tarkasteltaessa esimerkiksi lasten mielenterveyttä nimenomaisesti pedagogisena kysymyksenä on tarpeen kiinnittää huomiota siihen, minkä pedagogisen koulukunnan äänellä kulloinkin puhutaan.

Suomalaisessa kasvatuskeskustelussa - akateemisessa ja poliittisessa psykologia on viimeisten kolmenkymmenen vuoden aikana selvästi syrjäyttänyt filosofisen näkökulman. Tutkimuksen, teorianmuodostuksen ja 
kasvatuspolitiikan psykologisoituminen on muovannut keskustelemisen tapaa. Kysymykset kasvatuksen tarkoituksesta ovat väistyneet taka-alalle, ja huomiota on kohdistettu enenevästi menetelmiin, tekniikoihin, tehokkuuteen ja oppimisen kausaliteetteihin.

Kasvatusfilosofian pääkysymys on vanhastaan koskenut ihmisen kokonaiskehitystä kaikessa sen laajuudessa sisältäen sekä yksilön kehityksen että inhimillisen yhteiselämän näkökulmat. Pedagogiikka on ollut vastaamista siihen, mitä ihminen on ja mitä ihmisen pitäisi olla - tai paremminkin minkälaiseksi ihmisen pitäisi tulla - ja miten kasvatuksella voidaan edistää toivottuja ominaisuuksia. Ihmisen sekä yksilöllistä että kollektiivista kehityspotentiaalia on tarkasteltu tietämisen, moraalin, kauneudentajun ja uskonnollisen olemistavan kokonaisuutena. Visiona on ollut ihmisen kasvaminen täyteen määräänsä.

Nykypäivän psykologisoituneessa kasvatusajattelussa, koulutuspolitiikassa ja julkisessa kasvatuskeskustelussa keskitytään enenevästi siihen, mitä ihmisen pitäisi tietää ja taitaa. Tietokeskeinen eetos on alkanut dominoida laajasti kasvatus- ja sivistysajattelua. Ainakin tältä osin kasvatuksen ihmiskuva on yksipuolistunut ja kapeutunut. Tällä saattaa olla yhteys myös lasten ja nuorten mielenterveysongelmien kasvuun.

Yksipuolinen ihmiskuva väistämättä köyhdyttää paitsi kasvatusajattelua myös laajasti sosiaalista ja kulttuurista elämää. Sillä on seurauksensa niin ihmisten yksilöllisiin elämänorientaatioihin kuin sosiaalisten, taloudellisten ja poliittisten organisaatioiden toimintatapoihin. Näin se vaikuttaa laajasti lasten ja nuorten kasvuoloihin, siihen minkälaisessa yhteiskunnallisessa ilmapiirissä he varttuvat.

Kysymys nykypäivän kasvatuksen ihmiskuvasta ei rajoitu vain tiedollisten arvojen korostumiseen tietointensiivisessä ajassamme. Myös psykologisoituminen pelkistää ja yksipuolistaa kasvatusajattelua. Kun siihen liitetään psykiatriassa korostuva psykopatologinen lähestymistapa ja taloudellisen tehokkuuden ympärillä askaroiva talouspolitiikka, piirtyy eteemme kasvatuksen ajankuva. Tätä ajankuvaa vasten on paikallaan mietiskellä, miksi niin monen lapsen ja nuoren mielenterveys järkkyy.

Kaikkeen inhimilliseen toimintaan pätee sääntö, jonka mukaan käytäntö ilmentää ajattelua. Jos kasvatuksen käytännöissä tunnistetaan puutteita, on syytä kysyä, miten on kasvatusajattelun laita. Laadukas käytäntö on seurausta laadukkaasta ajattelusta, ei päinvastoin.

Vallitsevien kasvatusolojen ja -käytäntöjen arvioinnissa pääkysymyksen tulisi koskea sitä, miten olot ja käytännöt vastaavat kasvatuksen tarkoitusta. Nykypäivänä tosin tällaista kysymystä on hankala esittää, koska siihen vas- 
taamiseksi tarvitaan perusteltu käsitys kasvatuksen tarkoituksesta, josta ei juuri keskustella. Psykologinen ja sosiologinen kasvatustutkimus eivät voi lainkaan tätä kysyä, koska ne eivät voi siihen vastata.

Keskustelu kasvatuksen tarkoituksesta on inhimillisen olemassaolon ja maailmankatsomuksen ytimessä. Kasvatuksen perimmäinen tarkoitus ei voi olla muuta kuin elämän tarkoitus. Kasvatus, koulutus ja muu sivistystyö ovat tulevaisuuden rakentamista, ja visiota ei voi johtaa vallitsevasta todellisuudesta, koska se, mitä tavoitellaan, ei ole vielä olemassa. Käsitys tarkoituksesta ja tavoitteista muodostetaan a priori järkiperäisen päättelyn avulla.

Kasvatuksen tarkoituksen teoretisointi kuuluu filosofisen antropologian alaan. Empiirinen tutkimus ihmismielen ja inhimillisen yhteiselämän mekanismeista - psykologisista ja sosiologisista kausaliteeteista - voi tarjota tietoa kasvatuksen mahdollisuuksista ja rajoista suhteessa sen tarkoitukseen mutta ei itse tarkoituksesta. Paluu kasvatusopin perusteisiin on paluuta kasvatusfilosofiseen teorianmuodostukseen.

Nyky-Suomessa akateemisen kasvatusfilosofisen tutkimuksen hiipuminen ilmenee kasvatusfilosofisten opintojen vähenemisenä kasvatus- ja opetusalan ammattilaisten koulutuksessa ja kasvatusfilosofisen kysymyksenasettelun vajeena kasvatuspoliittisessa keskustelussa. Kuten kasvatusajattelussa ja -tutkimuksessa olisi palattava kasvatusopin perusteisiin, myös alan koulutuksessa olisi annettava tilaa perusteita luotaavalle pedagogiselle pohdiskelulle.

Kasvatusalalla tarvitaan kasvatusfilosofista näkökulmaa ja argumentaatiota. Sikäli kuin kasvatusfilosofia nähdään yhteiskunnallisen ja kulttuurisen edistyksen ydintekijäksi, se koskettaa sosiaalisten, taloudellisten ja poliittisten organisaatioiden kenttää laajasti. Kysymys kasvatuksen tarkoituksesta saa sekä eettisen että poliittisen sisällön. Haasteeseen vastaaminen vaatii sekä näkijöitä että tekijöitä.

Ihmiskunnan suuret kasvatusajattelijat ovat poikkeuksetta ymmärtäneet, että yhteinen tulevaisuus riippuu ratkaisevasti siitä, miten kasvatus on järjestetty. Kasvatus ja sivistys ovat sisäänrakennettuina yhteiskunnan kehityksessä. Poliittisestikaan ei ole samantekevää, minkälaisille filosofioille ne rakentuvat, ja yhteys jopa lasten ja nuorten mielenterveyteen on ilmeinen.

Kasvatuskäsityksistä ja -filosofioista puhuttaessa on paikallaan tehdä ero akateemisen kasvatusfilosofisen tutkimuksen ja kansalaisten kasvatusajattelussa ja -toiminnassa vaikuttavien kasvatuskäsitysten ja -aatteiden välille. Käytännössä nämä eivät kuitenkaan ole täysin erillisiä. On paljon esimerkkejä siitä, miten kasvatusajattelijat ovat vaikuttaneet yhteiskuntien kasvatuspoliittisiin linjanvetoihin. 
Mainio esimerkki tällaisesta vaikuttamisesta on katolisen vastauskonpuhdistuksen vuosina maanpakoon joutuneen tšekkiläisen Johan Amos Comeniuksen (1592-1670) useiden maiden vallanpitäjiltä saamat kutsut osallistua maan koululaitoksen kehittämiseen. Hän sai kutsun myös Ruotsiin, missä hän työskenteli vuosina 1642-1648 kirjoittaen oppikirjoja ja toimien koulupoliittisena neuvonantajana.

Esimerkkejä kasvatusfilosofien merkityksestä kansakunnan poliittisiin linjauksiin on useita. Comeniuksen ohella näytteiksi riittäkööt John Dewey (1859-1952), jolla oli keskeinen rooli USA:n koulureformeissa ja koulutuspolitiikan muotoutumisessa 1900-luvulla, ja oma kansallisfilosofimme J. V. Snellman (1806-1881), jonka syvällekäyvä vaikutus suomalaiseen sivistyspolitiikkaan on muovannut perustavalla tavalla koko yhteiskunnan henkistä perustaa.

Kasvatusfilosofia vaikuttaa ratkaisevasti sosiaaliseen ja kulttuuriseen kehitykseen määrittämällä niin yksilöiden kuin yhteisöllisenkin kehityksen lähtökohtia kasvatuksen näkökulmasta. Yksilöllisen ja kollektiivisen kehityksen vastavuoroisuus merkitsee sitä, että niitä on tarkasteltava samanaikaisesti, suhteessa toisiinsa. Käsitys kasvatuksen tarkoituksesta on kehys, jossa ja jonka suhteen tällainen tarkastelu ylipäätään on mahdollista.

Historia osoittaa, että ihmisen henkistä vapautta vaaliva yhteiskuntamuoto on kukoistavan kansalaistoiminnan edellytys ja vapaa kansalaistoiminta puolestaan yksilöllisen osallisuuden ja hyvinvoinnin kasvupohja. Yksilön kasvu itsenäisesti ajattelevaksi ja vastuulliseksi kansalaiseksi tapahtuu osallisuudessa tällaiseen yhteisöllisyyteen.

Itsenäinen ajattelu, moraalinen harkintakyky ja aktiivinen kansalaisuus eivät ole ihmisen synnynnäisiä ominaisuuksia. Niihin ei voi pakottaa vaan niihin on kasvettava. Yhteiskunta ja sen yhteisöt ovat se kasvuympäristö, joka luo tälle kasvulle reunaehdot. Ilman kasvatusfilosofista keskustelua tälle näkökohdalle verrannollisen kasvatuspolitiikan perusta jää kovin huteraksi.

On paikallaan kysyä, minkälainen kasvuympäristö tämän päivän oma yhteiskuntamme on lapsille ja nuorille, minkälaiset puitteet se tarjoaa heidän kehitykselleen henkisesti vapaiksi, itsenäisiksi ja vastuullisiksi yhteiskunnan jäseniksi ja minkälaisen sivistyksellisen ympäristön se tarjoaa aikuisille kansalaisille. Jos on ristiriitaa eettisesti perustellun kasvatuksen tarkoituksen ja vallitsevien kasvatuksellisten olojen välillä, ainut eettisesti kestävä ratkaisu on vaatia olosuhteiden korjaamista.

Kasvatuksen tarkoituksesta johdettu kasvatusoppi mahdollistaa vallitsevien kasvatusolojen kriittisen tarkastelun, pedagogisen yhteiskuntakritiikin. 
Ilman järkiperäistä kasvatuksen idean hahmottamista tulee kasvatuksesta helposti väline jollekin muulle, ja tämä muu voi olla täysin ristiriidassa kasvatuksen filosofisesti perustellun tarkoituksen kanssa. Deduktiivinen metodi tarjoaa mahdollisuuden poiketa ideologisesta valtavirrasta, kyseenalaistaa vallitsevia käytäntöjä ja keskustella niistä eettisinä kysymyksinä.

Viime aikoina länsimaisessa poliittisessa arvoyhteisössä on esiintynyt prosesseja, jotka ovat horjuttaneet sen perusteita. Äänestäminen kiinnostaa yhä harvempia, sananvapaudesta taitetaan ideologista peistä aina hullunkurisuuksiin asti, sosiaalisessa mediassa haukutaan surutta lähimmäisiä, vääristellään, maalitetaan, canceloidaan ja jopa poliittiset johtajat rikkovat soveliaisuuden rajoja. Minkälaiselta lasten ja nuorten kasvuympäristöltä tämä näyttääkään?

Tapakulttuurin muutos on kaiken kaikkiaan ilmeinen ja horjuttaa länsimaisen yhteiskuntamuodon moraalista perustaa. Politiikassa, hallinnossa, oikeusajattelussa ja tieteessäkin valistuksen rationaalisen toimintatavan perintö on joutunut antamaan tilaa totuuden jälkeisen ajan pyrkimyksille muuttaa maailmaa puhunnan kautta. Miten tämä mahtaakaan vaikuttaa maailmasuhdettaan ja maailmankuvaansa rakentavien lasten ja nuorten mielenterveyteen?

Myös kasvatuksen filosofian saralla on havahduttu kantamaan uudenlaista huolta länsimaisen yhteiskuntajärjestyksen kestävyydestä. Yksi huutavan ääni korvessa on yhdysvaltalainen Martha Nussbaum, joka katsoo, että humanistisen sivistyksen laiminlyövä, yksipuolisesti tiedolliseen kasvatukseen ja teknologiaan suuntautuva koulutuspolitiikka on suoranainen uhka demokratialle. Hänellä näyttäisi olevan sanottavaa koko maailmalle, myös Suomelle.

Kasvatuksen ideaa ei ratkaista huutoäänestyksellä, mutta ehkä nykypäivänä ainut riittävä argumentti kasvatusfilosofisen näkökulman tarpeellisuudesta kasvatustutkimuksessa ja kasvatuspoliittisessa keskustelussa, jonka poliittisten päättäjien ja kansalaisten enemmistö hyväksyy, on lopulta se, jossa osoitetaan sen merkitys taloudelle ja demokraattiselle yhteiskuntajärjestykselle. Argumentaatio ei kuitenkaan saa olla kasvatuksen määrittelemistä talouden ja politiikan kriteereillä.

Lasten ja nuorten pahoinvointi ilmenee monenlaisena oireiluna. Aivan kuten oireilulla ei ole vain yhtä yhteistä nimittäjää, sen taustaltakaan ei ole mahdollista nimetä vain yhtä aiheuttajaa - ellei sitten puhuta yleisluonteisesti kasvuoloista. Pedagogiikassa huomio kohdistuukin erityisesti kasvuoloihin: ei kysytä, mikä lapsissa ja nuorissa on vialla vaan mikä on vialla heidän kasvuoloissaan ja yhteisöllisissä suhteissaan. 
On ilmeistä, että lasten ja nuorten oireilua aiheuttavat ylimitoitetut odotukset ja niistä johtuvat suorituspaineet. Kilpailu on merkittävä osa nykypäivän suorituskeskeistä olemistapaa, ja siihen kuuluvat olennaisesti pettymykset, riittämättömyyden tunne, ahdistuneisuus ja jopa uupumus. Nuorten aikuisten kohdalla lisäksi kilpailu työpaikoista, työelämän osaamisvaatimukset ja tulevaisuuden epävarmuus lisäävät ahdistusta.

Voidaan aiheellisesti kysyä, onko koulusta ja kasvatuksesta tullut varttuvan sukupolven mielenterveyttä horjuttava tekijä, vaikka pitäisi olla päinvastoin. Ei voi välttyä ajatukselta, että taloudellisille intresseille valjastettu suorituskeskeinen ja kilpailuhenkinen kasvatuskulttuuri on nuorison mielenterveysongelmien varsinainen sylttytehdas. Jos näin todella on, tarvitaan kasvatusajatteluun radikaalia muutosta, joka ravistelee niin koululaitosta kuin yhteiskunnan muita instituutioita sekä laajasti koko suorituskeskeistä elämänmuotoa.

Pedagoginen muutostarve ei rajoitu vain kouluun ja koulupedagogiikkaan. Ihmisen suorituskoneeksi välineellistävä ajattelu on tunkeutunut laajalti myös kotikasvatukseen sekä lasten ja nuorten harrastuksiin. Muutos vaatii palaamista kasvatusopin peruskysymyksiin ja koskee läpikotaisin koko kasvatuskulttuuria, sen ihmiskuvaa, arvopohjaa ja elämänfilosofista juuristoa. Mielenterveys on liian kallis hinta uhrattavaksi millekään alttarille. 